\title{
Eating habits and body ideals from the Renaissance period to the present: Perspectives from paintings on nutrition and body image
}

\author{
Alexandros Karampetsos ${ }^{1}$, Dimitris Efthymiou ${ }^{2}$, Effrosyni Griva ${ }^{1}$, Christina Mesiari $^{1}$, Andrey V. Severin ${ }^{3,4}$, Emilia Vassilopoulou $^{1}$
}

\author{
AFFILIATION \\ 1 Department of Nutritional Sciences and Dietetics, School of Health Sciences, International Hellenic University, Thessaloniki, Greece \\ 2 2nd Department of Psychiatry, Sector of Neurosciences, School of Medicine, Faculty of Health Sciences, Aristotle University of Thessaloniki, \\ Thessaloniki, Greece \\ 3 Department of Analytical and Forensic Medical Toxicology, Sechenov University, Moscow, Russian Federation \\ 4. Laboratory of Toxicology, Medical School, University of Crete, Heraklion, Greece
}

\section{CORRESPONDENCE TO}

Emilia Vassilopoulou. Department of Nutritional Sciences and Dietetics, School of Health Sciences, International Hellenic University, GR-57400, Thessaloniki, Greece. E-mail: vassilopoulouemilia@gmail.com ORCID ID: https://orcid.org/0000-0002-2665-5908

\section{KEYWORDS}

body image, nutrition education, painting, eating patterns, art

Received: 13 April 2021, Revised: 27 June 2021, Accepted: 5 July 2021

Public Health Toxicol 2021;1(1):3

https://doi.org/10.18332/pht/139905

\begin{abstract}
INTRODUCTION Obesity, unhealthy eating habits and disordered eating behavior affect physiology and mental Visual arts, such as painting, have been shown beneficial in psychotherapy and stress-related disease management. Their impact on shaping eating habits and body image, and their possible use as a tool in health education for young people has not been thoroughly researched.

METHODS In this review, significant paintings from the 15th century until the present, depicting eating habits and body image through the centuries are presented in the light of their capacity to transfer information about the shaping of eating habits and body ideals. The current review was performed under the auspices of the Hellenic Center of
\end{abstract}

Education \& Treatment of Eating Disorders (KEADD). RESULTS Paintings constitute a useful vehicle for capturing the changing eating habits according to the sociopolitical status of each era and the perceptions/emotions related to foods. Therein, the foods may be recognized as healthy or unhealthy, rich or poor, and the body shape perceived as beautiful, attractive, or ugly, as the concepts of beauty change over time.

CONCLUSIONS The art of painting is a promising nutritional educational tool, serving as an agent for the promotion of a healthy body image. It can be utilized in imaginative school health education projects.

KEYWORDS art, painting, nutrition education, eating patterns, body image

\section{INTRODUCTION}

Food is essential for life, but eating habits show wide variation between populations and individuals and in different chronological periods. Desire to eat is regulated by physiological factors, such as hunger and satiety, but is also strongly affected by food associated environmental stimuli ${ }^{1}$. Consequently, frequent exposure to high salt, fat or sugar foods increases their consumption, while studies suggest that obesity-susceptible populations are more sensitive due to neural function ${ }^{1}$. Obesogenic stimuli like unhealthy food marketing alter eating habits in the short- term after exposure, especially in vulnerable age groups such as school-age children ${ }^{2}$. The complications of unhealthy food and increased body weight are devastating in both adults ${ }^{3}$ and children ${ }^{4}$, increasing both morbidity and mortality. Therefore, investing in tools for creating good prototypes of healthy eating and body weight is challenging.

Over the centuries, many famous and inventive painters have depicted on canvas the body ideals, food, and the influences of the prevailing civilization and culture on dietary choices, including the pain and hunger caused by war. The power of art in offering valuable knowledge on food and eating 
habits over time is well expressed, as represented by the Wansink and Wansink $\mathrm{k}^{5}$ survey. By collecting and comparing 52 paintings depicting one of the most famous meals in human history, 'The Last Supper of Jesus Christ' as narrated in the New Testament of the Bible, Wansink and Wansink ${ }^{5}$ calculated the per capita food ratio, and concluded that the serving sizes have increased linearly over the last millennium.

Since the Renaissance period there has been a parallel evolution of art and alimentary discoveries ${ }^{6}$, with Spain playing a catalytic role in both areas, due to its key geographical location. Throughout its history, Spain has been influenced by merchants from other parts of the Mediterranean, including the Phoenicians, who brought various sauces, the ancient Greeks, who brought olive oil, which became a key ingredient in the Spanish cuisine, and the Carthaginians and Romans who transferred the cooking methods of their cuisines ${ }^{7}$. Following the Colonial Wars and the discovery of the continent of America by Christopher Columbus in 1452, many new fruits, nuts, and vegetables, such as tomatoes, beans, and potatoes, were introduced to Spain, where they were grown or imported (e.g. cocoa) and incorporated in the Spanish cuisine ${ }^{8}$. The discovery of the potato was a milestone in the field of nutrition, and it has been one of the most important human foods for centuries. Originating in South America, it was introduced into Europe sometime in the 16th century. The first written evidence of the import of potatoes into Europe is a receipt dated 28 November 1567, issued by a potato exporter from the Canary Islands to an Antwerp merchant, and by the end of the 18th century, the potato had become very popular in France and neighboring countries ${ }^{9}$. Irish settlers were the first to introduce the potato to North America and cultivate it in the Londonderry area of New Hampshire in 1719.

The rise of middle class during the Renaissance resulted in an increase in the popularity of spices, and spice trading became the largest industry in the world ${ }^{10}$. Spices were condiments, used for flavoring, but they were also the main agents for conserving and preserving food. Spices, which are nowadays cheap and widely available, could at one time create enormous wealth. Spice trading created and destroyed empires, and even led to the discovery of new continents; America was discovered basically because Columbus was travelling 'to the other side of the earth', heading to India for spices. The discovery of America not only created empires, but also intensified the growing competition, sparking bloody conflicts over control of the spice trade. What is striking is that a small stick, such as cinnamon, cloves, or the seeds of a plant, such as cumin, would impel Europeans to embark on such tremendous, for that time, journeys. Disputes between European nations for sovereignty over the Spice Islands lasted for more than 200 years. As access to spices became easier, their value began to fall. Pepper and cinnamon are no longer luxury products and spices have lost their status and the charm that once made them worth as much as rare jewelry and precious metals, and responsible for circumnavigation of the globe ${ }^{11}$.

Europeans spread corn into Africa, and peanuts, beans, and tobacco into China. During the Renaissance, new standards in food preparation and preservation were created in Europe, while geographical exploration facilitated the spread of these new methods of food management ${ }^{12}$.

With the limitless eagerness to explore the world that characterized that period, and subsequent to the discovery of the new continent, the premises for a better life were established for people who travelled from one country to another, hoping to reach their dream. With their travels, they exchanged cultural characteristics, among the most significant of which were food products, cooking methods and eating habits.

The Fine Arts, and in particular painting, function as a means of disseminating information over the centuries, regarding, among other aspects of life, eating habits and body ideals. The purpose of this review was to compile a selection of paintings depicting eating patterns and body shapes from the 15th century to the present, and to explore the potential of the paintings to indirectly cultivate healthy eating habits and a balanced connection with body image. This potential is particularly pertinent in the present culture of instant digital communication of visual images via the social media and can be exploited imaginatively as the basis for health education in schools.

\section{METHODS}

Among the Fine Arts that extol beauty and aim to offer aesthetic pleasure, painting was selected for the purposes of this study. Artworks were selected in which food products, eating habits or body models were depicted, from the Renaissance period to the present. Several sources were used, starting with the magnificent exhibition of 'Van Gogh Alive - The Experience', where more than 3000 works of the great Dutch artist were presented through 3D representations ${ }^{13}$. The Museo del Prado in Madrid was the source of a large number of Spanish paintings from the 14th to the early 19 th century ${ }^{14}$. Important collections of paintings by Italian artists were reached through the Brera Gallery, in Milan, Italy ${ }^{15}$, and the Uffizi Gallery in Florence, which contains the largest collection from the Italian Renaissance $\operatorname{period}^{16}$.

The current review was performed under the auspices of the Hellenic Center of Education \& Treatment of Eating Disorders (KEADD). Search for historical references was conducted at the National Library of Greece ${ }^{17}$, and at the libraries of the School of Fine Arts in Athens ${ }^{18}$, the Department of Fine and Applied Arts of the Aristotle University of Thessaloniki ${ }^{19}$ and Fine Arts of the University of Western Macedonia in Florina ${ }^{20}$.

\section{RESULTS}

The Renaissance began in Italy, specifically in Florence during the 15th century, and spread throughout the Western world through the arts, literature, and sciences. 
During this time, art was dissociated from religion and became individualized. The concept of homo universalis was formed, that of a man who encompassed the ideals of the Renaissance: an inquiring and critical spirit, curiosity, and above all, a tendency to engage in every aspect of the arts and sciences. The term refers to the range or desired 'universality' of the polymathy that could be acquired ${ }^{21}$.

In 1480, Hieronymus Bosch portrayed the seven deadly sins, which, classified in increasing severity, are: sloth (acedia), pride (superbia), gluttony (gula), lust (lussuria), greed (avaritia), wrath (ira), and envy (invidia) ${ }^{22}$. Gluttony, or bulimia, refers to the consumption of extreme quantities of food, regardless of hunger, in a very short time, being first recorded as a problem in the 15 th century ${ }^{23,24}$. Nowadays, it is known that irrational consumption of fatty meats combined with alcohol exerts a negative impact on health, increasing the risk of diseases with high morbidity and mortality, such as obesity ${ }^{25}$, cardiovascular disease ${ }^{26}$ and cancer ${ }^{27}$. Bosch, following the precepts of the Catholic Church, illustrated the dangers of overeating to health, while satirizing human sins, defects and insanity. Throughout human history, religion has been seen to establish food choices and eating habits, with both positive and negative effects ${ }^{28}$.

The Renaissance reintroduced classical themes to art. 'La Primavera', spring, through the eyes of Sandro Botticelli (1482) presents beautiful semi-covered female and male figures, accompanied by Zephyrus and Cupid, in a scene from classical mythology, surrounded by over 500 plant species and 190 different flowers ${ }^{29}$. The bodies appear exuberant, surrounded by a plethora of nature's gifts ${ }^{30}$.

Painters, such as Perugino (1446-1523), Antonio Del Pollaiuolo (1433-1498) and Jan Gosaert (1478-1532), using classical art and naturalistic approaches, provide us with knowledge about the new religious and non-religious themes that appeared during the Renaissance ${ }^{31}$. During that period, both northern and Italian art presented the ideal human body similar to that of the ancient Greek classical period, completely symmetrical, reaching perfection. The 'Nude' was worshipped, and became central to artistic practice, as interest in classical antiquity was revived. During the same period, many artists focused on imprinting Christian worship on everyday life, resulting in the development of a newly vibrant representation of the human body. The ability to represent the naked body became a measure of the skill, intelligence, and originality of the artist. In parallel, portrayal of the naked body triggered controversies, especially in religious art, where the athletic, finely proportioned body, which for some communicated virtue, for others was considered to incite lust. A representative example of the creations of that period is the 'Christ on the Cold Stone' by the Flemish painter Jan Gossaert (1478), in which Christ is depicted as a handsome man with an athletic body ${ }^{32}$. In 'The Martyrdom of Saint Sebastian' (1739), a work of the Italian painter Giovanni Batista, the saint, while suffering his martyrdom, has an unripe beauty and perfect physique, with golden hair and white skin ${ }^{33,34}$.

Meanwhile, Leonardo Da Vinci created the portrait of 'Mona Lisa', the most mysterious woman throughout the history of painting; the woman with the emblematic smile, dark hair and white skin, wearing a delicate dark dress and veil, and with her eyes beholding the observer ${ }^{35}$. This is a piece of art that combines elegance and beauty, without any hint of nudity, that is unceasingly admired and increases levels of aspiration and research interest ${ }^{36}$.

In the 16th century, 'Mannerism' was born in Spain, as a reaction to the Renaissance. The term is derived from the Latin manierus, meaning 'way', and its use prevailed during the First World War. This style triumphed throughout almost all of Europe from 1530 until the end of the 16th century $^{37}$, providing indications of the dietary habits of the period. In the second half of the 16th century, Giuseppe Arcimboldo, in 'The Four Seasons' captured the seasonality of fruits, vegetables and plants in four profile portraits ${ }^{38}$, illustrating the capability of nature to transform according to circumstances, to ensure survival and to provide its commodities ${ }^{38}$. The distinction between urban and rural dietary patterns had been evident since the 16th century. In the cities, the products were distributed with relative ease and adequacy in the markets and the bazaars. A greater variety of products was available and more sophisticated cooking methods appeared in urban households, compared with the rural traditional fare. Urban residents, in addition to purchasing a wide range of fresh products, had the opportunity to consume ready-cooked food, bought from street vendors and open-air or covered shops. The administration of goods in the city market, however, could not always ensure the smooth circulation of food products. Frequent nutritional crises and inadequate distribution of products in the cities over that period are attested by accounts of the lack, adulteration, or high cost, of basic foods ${ }^{39}$.

Following that period, a new genre 'Singerie' emerged, of paintings of monkeys appearing in human costumes in anthropogenic environments. This fashion began in Flemish painting in the 16th century and was further developed in the 17th century, and is epitomized in 1600 by Franz Franken, with his work 'Monkeys Playing Backgammon', showing monkeys entertaining, while drinking wine and eating grapes ${ }^{40}$. The connection with the sensual Greek god Dionysus was emphasized, the god of the grape-harvest, winemaking and wine, of fertility, orchards and fruit, but also of festivity and the theatre, religious ecstasy and insanity ${ }^{41}$. The creation 'Two Monkeys', painted in 1562 by the Flemish painter Pieter Brueghel de Jongere, depicts two figures chained to the windowsill of a fortress in Antwerp overlooking the river Seld ${ }^{42}$. The oppression of the Flemish villagers by the Spanish occupation, and the prevalent hunger, are distinctly portrayed by the few walnut shells and the posture of the monkeys ${ }^{43}$.

At the end of the 16th century, different interests were 
aroused within Spanish artists, possibly inspired by exchanges with foreign painters and artistic development in a wider cultural environment. At this time, the 'Still Life' genre made its appearance, either autonomously or as a complement to more complex scenes. The term 'still life' describes a work of art that depicts a composition of inanimate objects, which may be either natural, such as flowers, fruit and vegetables, and dead animals (destined for the table), or artificial, such as vases, various utensils and books ${ }^{44}$. The Spaniards of the following century would become unsurpassable in this genre.

The 16th century was also an initial period of apotheosis of the fleshy female body. The portrayal of the naked body of the goddess Venus is a hymn to the classical beauty and purity of the soul and has been used by many artists to depict the beauty of nudity. Their paintings reveal the influence of the prevailing body standards of the time. In the mid 16th century, the artist Tiziano Vecellio emerged to shake-up the field of Art. Specifically, in his work 'Venus Rising from the $\mathrm{Sea}^{\prime 45}$, the female figure is depicted emerging from the sea in beautifully revealing nudity, without any attempt to hide anything of her well-endowed, shapely body. In Botticelli's earlier painting of the same subject, 'The Birth of Venus' (c.1484-1486), the ideal of a well-shaped, curvaceous naked body prevails, inspired undoubtedly by the female bodies of that time, with bright colors and clear body lines ${ }^{46}$. Titian chooses to capture the figure of Venus based on later body standards, with more voluptuous curves and a firmer body type than all her previous depictions. It is of interest that during this period the first sugar factories were established in London, and the sausage industry was developed extensively in France, Germany and Italy ${ }^{47}$.

In the early 17 th century, Caravaggio twice portrayed 'Supper at Emmaus', satirizing the different social classes of the time, through the supper of Jesus with the citizens of Palestine. The differences are evident from the contents of the table and the faces of those depicted ${ }^{48}$.

In general, the 17th century is defined by the Baroque movement, expressed in painting, but also in literature, sculpture, architecture, music, and politics. This century is also marked by the Dutch Golden Age, the Grand Siècle of Louis XI of France, the Scientific Revolution, and according to some historians, the General Crisis. The cultural backdrop of Spain during the Golden Age is characterized by mental vitality and intelligence, and a fashion for riddles and the illustrated puzzles that painters used to conceal hidden messages in their works ${ }^{49}$. The 'Bodegón' genre (literally 'tavern' in Spanish), or still life in general, became very popular in 17 th century Spanish society as a non-religious type of painting, often with a hidden symbolic message within the theme presented. The main proponents of Bodegón were Diego Velazquez, Bartolomé Esteban Murillo, and David Teniers. In 1620, Diego Velazquez painted 'The Waterseller of Seville' in which an old water seller gives a glass of water to a young boy, while a man behind them drinks from a mug. Some advocate that this painting may symbolize thirst, or, considering the allegory of the three ages presented, the mature man gaining knowledge. The tall crystal glass offered by the water seller reveals a fig through the transparency of the liquid, displaying the practice of that time of adding figs to the water to provide aroma or to add nutrients to prevent hunger and disease ${ }^{50}$.

In that period, kings lived in luxury and remained healthy by eating well, as characteristically presented in the famous painting by Velazquez, 'The Maids of Honor'51, which portrays the Infanta Margarita Teresa, daughter of Louis IV and the new queen. One of the maids of honor is offering to the Infanta Margarita Teresa aromatic clay for calcium adequacy and proper development. During that period the Spaniards were defeated by the French, under King Louis XI, Spain fell under the occupation of the House of Bourbon ${ }^{52}$, and the Spanish bourgeoisie suffered from hunger as shown in the work of Bartolome Esteban Murillo, 'The Young Beggar'53.

Two works that reflect the eating habits of the time in northern Europe are those of Jan Steen, 'Wine is a Mocker' (1668-1670) and Vermeer 'The Girl with the Wine Glass' (1660), in which the result of large amounts of wine consumption and its use for seduction are clearly depicted ${ }^{54}$. The red socks on the woman at the table in Steen's painting indicate a woman of loose morals ${ }^{55}$. In general, Rembrandt, Paris Bordone, Lucas Cranach and Jan Steen were among the most important painters of 17th century Dutch art who captured prostitution in their works. Typical examples are the above two works, and another painting by Steen, "The Oyster Eater/Girl Offering Oysters ${ }^{56}$.

At the end of the 17th century and the beginning of the 18th, a new movement emerged that is considered spiritual, the 'Enlightenment'57. During this era, an ordinary meal consisted of a piece of bread, an onion, a few olives or a piece of cheese or salted meat, legumes, greens and a little, if any, wine. Grain in the form of bread or porridge containing cereals, and cheese or butter, onions, and oil, are the staples, and water would be drunk. An exception to such daily meals would be made on major Christian holidays when meat would be the main dish. Kings and nobility of the time, meanwhile, would eat fresh eggs, figs and grapes and drink red wine. They did not consume any vegetables. The royal manual mentions 'apotheosis of wheat, emphasis on meat and two main meals a day'. In 1760 the Industrial Revolution began, starting from Western Europe. New machines begin to be built, greatly facilitating farmers in cultivation, reducing working time and effectively contributing to increased production $^{58}$.

The 19th century was marked by significant developments in science and technology. The mechanization of agriculture, the creation through breeding techniques of new and improved varieties of plants and animal species, and the evolution of the food industry all contributed to the upgrading of the quality, quantity and variety of goods used by man for his food ${ }^{58}$. The year 1809 marked a milestone 
in the history of food preservation. The French chef Nikola Appert announced the results of his research on the preservation of food in closed glass jars which he sterilized by immersion in boiling water, thus laying the foundations of canning ${ }^{12}$.

Edouard Manet, the forerunner of the 'Impressionist' movement, captured in his work 'A bar of the Folies-Bergère', extolling modern life in Paris. Bottles of champagne, beer and wine can be seen at the bar, reflecting that alcohol was part of Parisian life ${ }^{59}$.

Vincent Van Gogh wrote to his brother Teo, on the occasion of his painting 'The Potato Eaters' ${ }^{60}$ : 'I have tried to emphasize how these people eat potatoes in the light of the lamp, dig the earth with the same hands that now touch the plate. I'm basically talking about manual labor and how these people have earned their living honestly. (...) My painting praises manual labor'. Starting with the potato, as food for the poor and the afflicted, the painter of the peasants and the hard life, composed this, his favorite painting, in 1885. Its protagonists, the suffering faces and the hands, gnarled from hard work, of the peasants. All the creator's touches are studied. 'Smells of ripe cobs, potatoes, fertilizers and manure, because that's how the field smells.' The potato continues its course in history as the food of the poor, identified with human labor ${ }^{61}$.

At that time, in parallel, changes were being made in the depiction of the standards of beauty in Art; Alexandre Cabanel created a markedly different image of 'The Birth of Venus' from that of Botticelli. The change in body shape is evident in the late 19th century. As in ancient Greece, the portrait of the goddess of beauty reproduced in the Renaissance was of a female form with curves, refined, with symmetrically balanced proportions. In contrast, the 19th century artists continued to depict the model of the ideal woman with generous curves, but much more exuberant, with no particular balance of proportions ${ }^{62}$.

The 20th century was marked by the two World Wars but was also characterized by the progress of Science. At the beginning of the 20th century, nutrition science was still an 'infant', but growing rapidly. Many important advances in the field of nutritional knowledge were made between 1910 and 1960 , with the discovery of various nutrients and elucidation of their biochemical relationship to human health ${ }^{58}$. In the 1900s with his paintings of 'Mother and Child' Pablo Picasso declares that there is no room for affection between the two because of hunger and poverty ${ }^{63}$. In 1936, Salvador Dali portrayed the 'Soft Construction with Boiled Beans: Premonition of Civil War', referring to the Spanish Civil War, which lasted until $1939^{64}$. The winners of this civil war were Franco's nationalist forces, openly supported by Adolf Hitler. The soft structure of the human mass is accompanied by a few boiled beans because, as Dali explains, no one could swallow all that subconscious meat without the presence of a few floured and melancholic beans. In general, Dali was pro-Hitler, and this is evident in his works of the late 1930s,
'Autumnal Cannibalism' and 'The Enigma of Hitler' (1939) ${ }^{65,66}$. In all three of his works, Dali presents hunger, fear and poverty in a brilliant way, depicting beans and bread ${ }^{67}$. These two comestibles are used during times of war, as legumes and flour are not perishable and can stand the test of time. Hitler's occupation brought great hunger and misery to the people, and this is conspicuous in many works of artists of the time ${ }^{68}$.

Meanwhile, the era of great change in Art has arrived. Impressionism is considered the greatest movement of the 20th century. Physical standards take a different shape, with the Queens of Great Britain holding the lead in this change. The image includes a narrow waist (certainly helped by corsets) and an hourglass-shaped body, along with long hair, a sign of femininity that sets them apart from workmen. A characteristic work of capturing this body image is Manet's 'Olympia'69,70. Pablo Picasso is also considered an artistic leader of this era, demonstrating great zeal for the creation of a large number of works of art. Attention to the body, due to its monumental plasticity, appears to derive from the rediscovery of antiquity through the works in the Louvre. Picasso experiments with the work 'Nude with Crossed Legs' (1903), making the colors in the paintings open and lighter, while the body becomes firmer ${ }^{71}$. Finally, the discovery of the statue of Venus by Willendorf, found in 1908 in Australia, depicts a rounded pear-shaped body with sizeable breasts. In the famous statue of Aphrodite of Milos the body is curvaceous, but the breast is small ${ }^{72}$.

Nowadays, the food industry is based on the science of food technology that aims to keep raw food sustainable and to create a wide variety of foods with therapeutic characteristics or a high content of nutrients, known as functional foods and superfoods, respectively ${ }^{73}$. Life and art run in an extreme speed. Contemporary Art, affected by the technological revolution and digital technology, is constituted by artists who draw their inspiration from innovative science and advanced technologies, creating a multifaceted convergence between art, technology and science ${ }^{74}$. Refined food products have taken a significant place in peoples' diet, resulting in obesity. At the other extreme, eating disorders preoccupy a significant proportion of mainly young people, influenced by the trend for fashion models to be tall and thin $^{75}$. As a culmination, in Brooklyn, Kara Walker created a giant sphinxlike woman from Styrofoam coated in sugar ${ }^{76}$ and contemporary artists depict the female body in extremes: obese, very lean, dissolved by disordered eating ${ }^{77}$.

The creations of artists emanate myriads of stimuli that can influence the spectator at multiple levels. The journey through selected paintings of great artists from the Renaissance onwards, observed under the prism of exploration of the eating habits and definitions of beauty and body image throughout the ensuing periods, offers incomparable information (Figure 1).

The study and comparison of selected works of art, which project the different body ideals and food cultures across the 
Figure 1. The female body in the eyes of Boticelli (La Primavera), Cabanes (Venus), Da Vinci (Mona Lisa), Picasso (Woman with crossed legs)
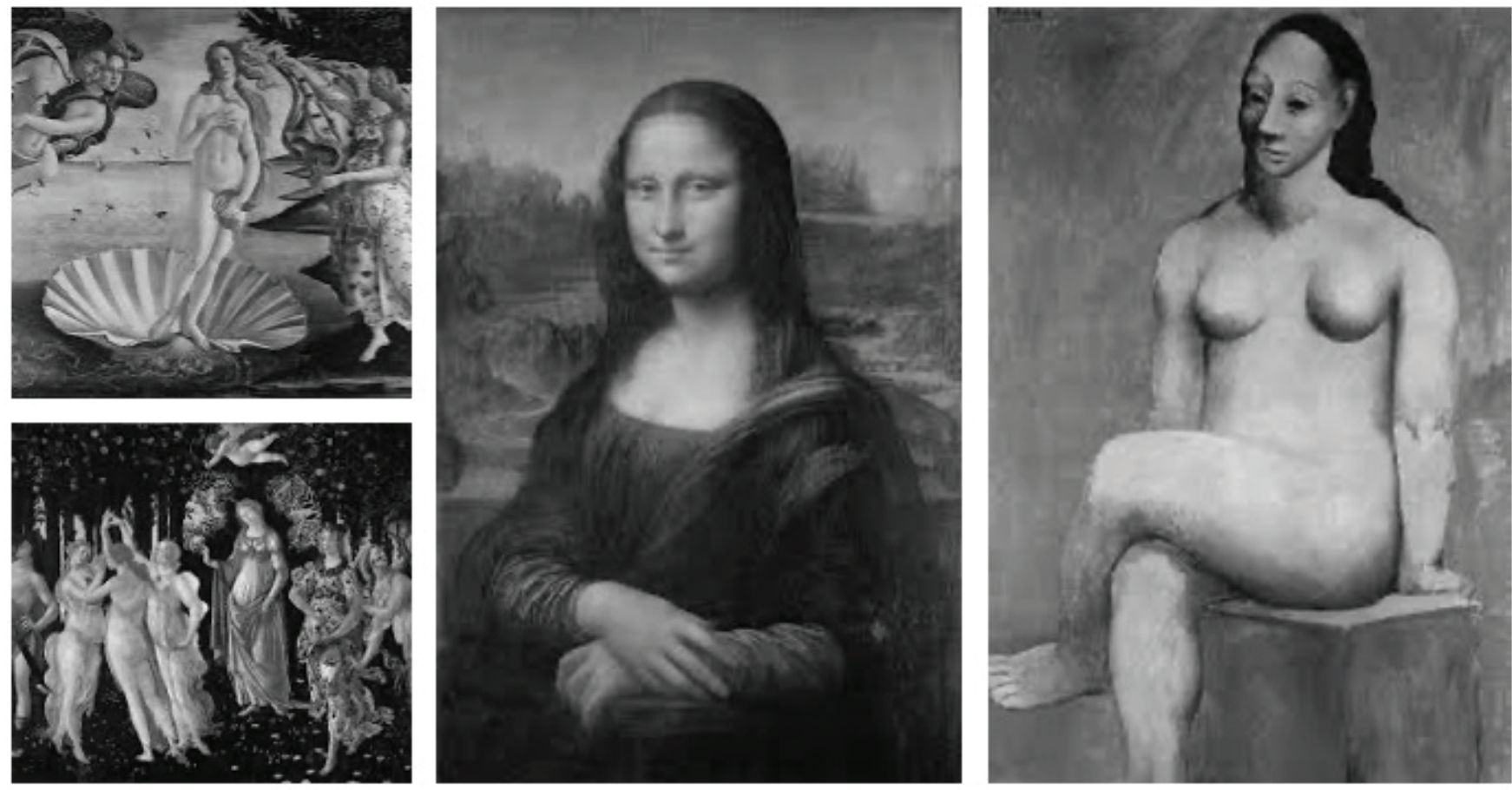

centuries, can provide the stimulus for nutrition education. The living circumstances of their times influenced the artists, who depicted real life as it was, but also or allegorically. Wars, hardship, hunger, and the misery of nations, but also the extreme affluence of the royalty and nobility fill the scenes of the various paintings. Some artworks depict populations poor and oppressed, but who, nevertheless, observed healthy eating habits, in terms of today's definition ${ }^{78}$. The fruits and vegetables that high society would reject were depicted in their daily diet, with vegetable soups, dairy products, herbs, nuts and fruit filling the tables of the villagers. The lower societal classes often had a better-quality diet by cultivating and consuming their seasonal products. Nowadays, ironically such 'health food' is the more expensive, while less nutritional refined products cost less ${ }^{79}$.

The fine arts, including painting, have the potential to heal and to educate, recognized in its Constitution by the World Health Organization (WHO), approaching health and disease holistically ${ }^{80}$. Writing, painting, music, dance, singing and chants have been used throughout history as a healing technique ${ }^{81}$.

Music, the most extensively researched art medium, has been shown to be beneficial in soothing anxiety and depression, and restoring emotional balance ${ }^{82,83}$. Research on the effect of music on pain has revealed its beneficial attributes, especially when the participants are singing ${ }^{84,85}$. Better outcomes of surgery are observed ${ }^{86}$, with reduction of the duration of hospital stays, as a result of the of patients listening to music ${ }^{87}$.

The visual arts, such as textiles, painting and pottery, have been shown to increase the overall health of cancer sufferers, by increasing optimism, socialization, self-esteem and selfexpression, especially in high-anxiety periods such as during chemotherapy ${ }^{88}$. Women with cancer felt more relaxed and creative when painting themselves on canvas or engaging in yoga and meditation ${ }^{89}$.

Viewing visual art expression via television, films and on digital devices, in general has been shown to influence perceptions of health and well-being ${ }^{90,91}$, with a considerable impact of social media on people's psyche. A variety of digital applications, such as Instagram, Facebook, and Twitter, have invaded people's lives. They can also function as modern channels of art distribution to the public, influencing the emotions, but also daily life, lifestyle, dietary patterns, and body image.

The ramifications of these patterns, with the emotions evoked, are extensive and the impact on the online audience is undeniable, but controversial, with enjoyment and positive effects, but also possible negative psychological consequences, leading to depression, insecurity and feelings of inadequacy and emptiness ${ }^{92}$. Through these digital platforms, the viewer is given the opportunity to express his/ her inner world and, in turn, integrate his/her art - paintings, photographs or videos - into the contemporary art of the 21st century ${ }^{93-95}$.

As image is the basic principle of the social media, 
the users are set up to present themselves without imperfections. A vicious circle of comparison leads to altered reactions and behavior, which can be very arduously for anyone who feels 'incompetent' if unable to adapt to the standards of the other users. Currently, media analysts and anthropologists support the overall view that social sharing through these platforms often results in feelings of dissatisfaction. A large proportion of people using the social media desire a lifestyle different from their own, and search for it in the online world. The link between body dissatisfaction and disordered eating attitudes and the expansion of social media use is undeniable ${ }^{96}$. Body image concerns are increasingly affecting a high proportion of people negatively, mainly children and adolescents, and this effect is closely related to the use of social networking sites ${ }^{97}$.

The modern forms of visual art should not be discounted, but digital techniques should be used to benefit the mental and physical health of the users. Their power to spread vast amount of visual information in seconds could be used to educate the users about healthy lifestyles, balanced body and mind, and healthy eating, and such messages should be guided by health professionals. A concerted effort by artists and health professionals could offer online artworks, where the ideal body is the healthy body, and healthy eating is not restricted eating but a balanced diet $^{98}$.

Art, as seen from this review, dismisses all stereotypes, and study of painting through the centuries confirms that there is, in fact, no fixed standard, and that regardless of whether the body is slender or voluptuous, strong or languid, lean or with rich curves, it has always provided an ideal of beauty.

A route for spreading educational art for promotion of discourse on eating habits and body image could be via modern visual arts and the social media, aimed at relieving stress and anxiety regarding body and food. The aim would be to alleviate distress, as it will not promote the 'perfect' but the 'real', through the contemporary channels of circulation of information, with their immediacy and constant updates ${ }^{99}$.

\section{CONCLUSIONS}

The interventions that improve health through art are largely undocumented, but the results so far are largely promising, thus building the foundation for ongoing research on this topic. Art has already been shown to be a promising tool for complementary treatment of disease or alleviation of symptoms in a range of conditions, such as psychological disorders, anxiety and stress, metabolic disorders, sleep disorders, and cancer. It can facilitate the patient in communicating his/her feelings when encountering barriers in verbal communication, the creative process being beneficial for mental health. Although in its infancy, research on the potential of the use of art in health preservation and the prevention and treatment of disease, shows promise. At an even earlier stage of development and application is the use of art in nutrition education and therapy, including the prevention and treatment of eating disorders. With confidence in the field of scientific evolution, art can be incorporated to facilitate nutritional education. The combination of a healthy diet and a healthy body image will have equally promising results regardless of gender, age and other factors that may play a role in the treatment of any disease. The use of paintings to generate discussion on food and body image can be incorporated in school healtheducation programs.

\section{REFERENCES}

1. Oginsky MF, Goforth PB, Nobile CW, Lopez-Santiago LF, Ferrario CR. Eating 'Junk-Food' Produces Rapid and LongLasting Increases in NAc CP-AMPA Receptors: Implications for Enhanced Cue-Induced Motivation and Food Addiction. Neuropsychopharmacology. 2016;41(13):2977-2986. doi:10.1038/npp.2016.111

2. Sadeghirad B, Duhaney T, Motaghipisheh S, Campbell NR, Johnston BC. Influence of unhealthy food and beverage marketing on children's dietary intake and preference: a systematic review and meta-analysis of randomized trials. Obes Rev. 2016;17(10):945-959. doi:10.1111/obr.12445

3. Abdelaal M, le Roux CW, Docherty NG. Morbidity and mortality associated with obesity. Ann Transl Med. 2017;5(7):161. doi:10.21037/atm.2017.03.107

4. Kansra AR, Lakkunarajah S, Jay MS. Childhood and Adolescent Obesity: A Review. Front Pediatr. 2021;8:581461. doi:10.3389/fped.2020.581461

5. Wansink B, Wansink CS. The largest Last Supper: depictions of food portions and plate size increased over the millennium. Int J Obes (Lond). 2010;34(5):943-944. doi:10.1038/ijo.2010.37

6. Van Hee R. Wijzigingen in voedingsgewoonten en ziekteverschijnselen in de $16 \mathrm{e}$ en $17 \mathrm{e}$ eeuw. Changes in eating habits and disease symptoms in the 16th and 17th centuries. Article in Dutch. Verh K Acad Geneeskd Belg. 1996;58(3):271-283

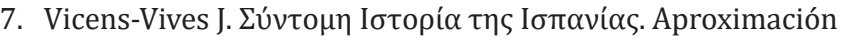
a la historia de España. Book in Greek. Aíoגos; 1997.

8. Lindqvist, H. Christofer Columbus: var han riktigt klok?. Fischer; 2003.

9. Earle R. Promoting Potatoes in Eighteenth-Century Europe. Eighteenth-Century Studies. 2017;51(2):147-162. doi:10.1353/ecs.2017.0057

10. Petrovska BB. Historical review of medicinal plants' usage. Pharmacogn Rev. 2012;6(11):1-5. doi:10.4103/0973-7847.95849

11. Freedman P. ПЕРА АПО THN АNАTO $\Lambda$ H: MПАХАРIKA KAI

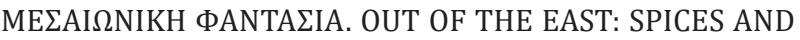
THE MEDIEVAL IMAGINATION. Book in Greek. KONI $\triangle A P H \Sigma$; 2010.

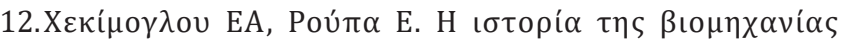
$\tau \rho \circ \varphi(\mu \omega \nu$. [The history of food industries]. Book in Greek.

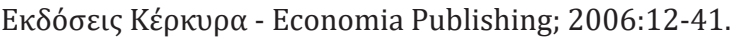

13.Van Gogh Museum: Amsterdam, Netherlands. Google Arts \& Culture. Accessed June 27, 2021. https://artsandculture. 
google.com/partner/van-gogh-museum

14. Museo Nacional del Prado. Accessed June 27, 2021. https:// www.museodelprado.es/en

15. Pinacoteca di Brera. Accessed June 27, 2021. https:// pinacotecabrera.org

16. Le Gallerie degli Uffizi: Firenze, Italy. Google Arts \& Culture. Accessed June 27, 2021. https://artsandculture.google.com/ partner/uffizi-gallery

17. National Library of Greece. Accessed June 27, 2021. https:// www.nlg.gr/

18. Athens School of Fine Arts Library. Accessed June 27, 2021. http://www-en.library.asfa.gr/askt/site/Home/t_section

19. School of Visual and Applied Arts, Faculty of Fine Arts. Accessed June 27, 2021. https://www.vis.auth.gr/en/

20. Department of Applied and Fine Arts. Accessed June 27, 2021. https://eetf.uowm.gr/en/

21. Snieder R. The tube worm turns. Nature. 2000;406(6799):939. doi:10.1038/35023062

22. Table of the Seven Deadly Sins. Museo del Prado. Accessed June 27, 2021. https://www.museodelprado.es/en/ the-collection/art-work/table-of-the-seven-deadlysins/3fc0a84e-d77d-4217-b960-8a34b8873b70

23. Blinder BJ, Cadenhead K. Bulimia: a historical overview. Adolesc Psychiatry. 1986;13:231-240.

24.Bemporad JR. Cultural and Historical Aspects of Eating Disorders. Theor Med. 1997;18(4):401-420. doi:10.1023/A:1005721808534

25. Recaredo G, Marin-Alejandre BA, Cantero I, et al. Association between Different Animal Protein Sources and Liver Status in Obese Subjects with Non-Alcoholic Fatty Liver Disease: Fatty Liver in Obesity (FLiO) Study. Nutrients. 2019;11(10):2359. doi:10.3390/nu11102359

26. Hashemian M, Merat S, Poustchi H, et al. Red Meat Consumption and Risk of Nonalcoholic Fatty Liver Disease in a Population With Low Meat Consumption. Curr Dev Nutr. 2020;4(Suppl_2):1413-1413. doi:10.1093/cdn/nzaa061_041

27. Kotepui M. Diet and risk of breast cancer. Contemp Oncol (Pozn). 2016;20(1):13-19. doi:10.5114/wo.2014.40560

28. Leung $\mathrm{FH}$, Leung A. Bless me, for I have sinned ...: Behaviour change and the confessional. Can Fam Physician. 2009;55(1):17-18. Accessed June 27, 2021. https://www.cfp. ca/content/cfp/55/1/17.full.pdf

29. Botticelli's Primavera. ItalianRenaissance.org. Accessed June 27, 2021. http://www.italianrenaissance.org/a-closer-lookbotticellis-primavera/

30.Lazzeri D. Concealed lung anatomy in Botticelli's masterpieces the primavera and the birth of venus. Acta Biomed. 2018;88(4):502-509. doi:10.23750/abm.v88i4.5981

31. Haughton N. Perceptions of beauty in Renaissance art. J Cosmet Dermatol. 2004;3(4):229-33. doi:10.1111/j.1473-2130.2004.00142.x

32. Jan Gossaert (Mabuse) - Christ on the Cold Stone (1527). alamy.com. Accessed June 27, 2021. https://www.alamy. com/jan-gossaert-mabuse-christ-on-the-cold-stone-1527image211045366.html
33. The Martyrdom of Saint Sebastian: Antonio del Pollaiuolo and Piero del Pollaiuolo. The National Gallery, London. Accessed June 27, 2021. https://www.nationalgallery.org.uk/ paintings/antonio-del-pollaiuolo-and-piero-del-pollaiuolothe-martyrdom-of-saint-sebastian

34. Barale M, Guaraldi F. The martyrdom of Saint Sebastian. J Endocrinol Invest. 2015;38(3):375. doi:10.1007/s40618-014-0173-7

35. Scailliérez C. Mona Lisa - Portrait of Lisa Gherardini, wife of Francesco del Giocondo. The Louvre Museum. Accessed February 25, 2021. https://web.archive.org/ web/20210225025759/https://www.louvre.fr/en/oeuvrenotices/mona-lisa-portrait-lisa-gherardini-wife-francescodel-giocondo

36. Yafi M. Mona Lisa is euthyroid: a modern-day diagnosis. Hormones (Athens). 2019;18(3):331-332. doi:10.1007/s42000-019-00103-x

37. Charlier P, Lippi D, Perciaccante A, Appenzeller O, Bianucci R. Neurological disorder? No, Mannerism. Lancet Neurol. 2019;18(2):135. doi:10.1016/S1474-4422(18)30447-2

38. Kriegeskorte W. Giuseppe Arcimboldo, 1527-1593. Taschen; 2004.

39. Martini M, Bellavitis A. Household economies, social norms and practices of unpaid market work in Europe from the sixteenth century to the present. Hist Fam. 2014;19(3):273282, doi:10.1080/1081602X.2014.933999

40. Ferdinand van Kessel - Monkeys Playing Backgammon. MutualArt.com. Accessed June 27, 2021. https:// www.mutualart.com/Artwork/Monkeys-PlayingBackgammon/22A65D6F67316D49

41.Lurie S. CARSKI REZ U GRČKOJ MITOLOGIJI. CAESAREAN SECTION IN ANCIENT GREEK MYTHOLOGY. Acta medhist Adriat. 2015;13(1):209-216. Accessed June 27, 2021. https://hrcak.srce.hr/file/209773

42.Pieter Bruegel the Elder: Two Monkeys, 1562. Gemäldegalerie. Staatliche Museen zu Berlin - Preußischer Kulturbesitz. Accessed June 27, 2021. https://www.smb. museum/en/museums-institutions/gemaeldegalerie/ collection-research/conservation-care/pieter-bruegel-theelder-two-monkeys-1562

43. Potter P. The Monkey's Paw . Emerging Infectious Diseases. 2011;17(9):1785-1786. doi:10.3201/eid1709.ac1709

44. Abbing A, Ponstein A, van Hooren S, de Sonneville L, Swaab H, Baars E. The effectiveness of art therapy for anxiety in adults: A systematic review of randomised and non-randomised controlled trials. PLoS One. 2018;13(12):e0208716. doi:10.1371/journal.pone.0208716

45.Venus Rising from the Sea, 1520 by Titian. titian.org. Accessed June 27, 2021. https://www.titian.org/venusrising-from-the-sea.jsp

46. Deimling B, Michael Claridge. Sandro Botticelli, 1445-1510: the evocative quality of line. Taschen; 2019:44-46.

47. Lazzeri D, Nicoli F, Zhang Y. Secret hand gestures in paintings. Acta Biomed. 2019;90(4):526-532. doi:10.23750/abm.v90i4.7134

48. Supper at Emmaus. Caravaggio Gallery. Accessed June 27, 
2021. https://www.caravaggiogallery.com/supper-atemmaus.aspx

49. Potter P. Genre painting and the world's kitchen. Emerg Infect Dis. 2005;11(1):188-189. doi:10.3201/eid1101.AC1101

50. Miller OA. Velázquez, The Waterseller of Seville. Khan Academy. Accessed June 27, 2021. https://www. khanacademy.org/humanities/renaissance-reformation/ baroque-art1/spain/a/velzquez-the-waterseller-of-seville

51.Las Meninas, 1656 by Diego Velazquez. Diego Velazquez: Paintings, Quotes, and Biography. Accessed June 27, 2021. https://www.diego-velazquez.org/las-meninas.jsp

52. Wolf N. Diego Velazquez 1599-1660: the face of Spain. Taschen; 2016

53. The Young Beggar 1650 by Bartolomé Esteban Murillo (Museum: Department of Paintings of the Louvre). useum. org. Accessed June 27, 2021. https://useum.org/artwork/ The-Young-Beggar-Bartolome-Esteban-Murillo-1650

54. The Girl with a Wine Glass (Dame en twee heren). essentialvermeer.com. Accessed June 27, 2021. http://www. essentialvermeer.com/catalogue/girl_with_a_wine_glass.html

55. Wine is a Mocker - Jan Steen. AllPainters.org. Accessed June 27, 2021. https://allpainters.org/paintings/wine-is-amocker-1670-jan-steen.html

56. Jan Steen, Girl Eating Oysters, c. 1658 - 1660. Mauritshuis.nl. Accessed June 27, 2021. https://www.mauritshuis.nl/en/ explore/the-collection/artworks/girl-eating-oysters-818/

57. Friedlaender GE, Friedlaender LK. Art in Science: William and John Hunter-Gifts of the Enlightenment. Clin Orthop Relat Res. 2019;477(4):700-704. doi:10.1097/CORR.0000000000000701

58. Ashton ST. H BIOMHXANIKH EПANA $\Sigma$ TA $\Sigma H$. THE INDUSTRIAL REVOLUTION. Book in Greek. TOПОГ; 2007.

59. A Bar at the Folies-Bergère: Édouard Manet. The Courtauld Institute of Art. Accessed June 27, 2021. https:// courtauld.ac.uk/gallery/collection/impressionism-postimpressionism/edouard-manet-a-bar-at-the-folies-bergere

60. The Potato Eaters: Vincent van Gogh (1853 - 1890), Nuenen, April-May 1885. Van Gogh Museum. Accessed June 27, 2021. https://www.vangoghmuseum.nl/en/collection/ s0005V1962

61. Walther IF, Metzger R, Hulse M. Vincent van Gogh: the complete paintings. Taschen; 2012.

62. The Birth of Venus: Alexandre Cabanel, 1863. Google Arts \& Culture. Accessed June 27, 2021. https://artsandculture. google.com/asset/the-birth-of-venus/awEIYqoUcAJ6TA

63. Mother and Child, 1921 by Pablo Picasso. Pablo Picasso: Paintings, Quotes, \& Biography. Accessed June 27, 2021. https://www.pablopicasso.org/mother-and-child-1921.jsp

64. Soft Construction with Boiled Beans (Premonition of Civil War), 1936, Salvador Dalí, Spanish, 1904 - 1989. Philadelphia Museum of Art. Accessed June 27, 2021. https://www. philamuseum.org/collection/object/51315

65. Autumnal Cannibalism. salvadordaliprints.org. Accessed June 27, 2021. http://salvadordaliprints.org/autumnalcannibalism/
66. The Enigma of Hitler, 1939 by Salvador Dali. Salvador Dali: Paintings, Biography, and Quotes. Accessed June 27, 2021. https://www.dalipaintings.com/the-enigma-of-hitler.jsp

67. Robert Descharnes R, Néret G. Salvador Dali: the paintings 1904-1989. Taschen; 2020:163-166.

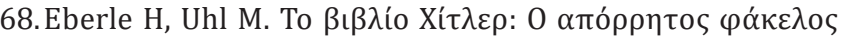

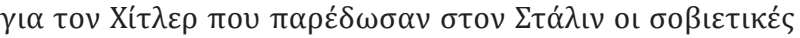

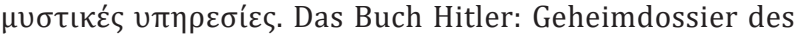

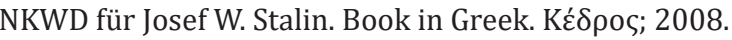

69. IMPRESSIONISM flavours Physicians' Art Salon. Can Hosp. 1951;28(8):47.

70. Wear D. Painters and patients: how art informs medicine. Fam Med. 1991;23(7):531-533.

71. Pablo Picasso: Nude Woman with Crossed Legs Crowned, with Flowers (Femme nue couronnée de fleurs, aux jambes croisées) from the Vollard Suite (Suite Vollard) 1930, published 1939. MoMA.org. Accessed June 27, 2021. https:// www.moma.org/collection/works/61396

72. Cheng TO. Obesity, Hippocrates and Venus of Willendorf. Int J Cardiol. 2006;113(2):257. doi:10.1016/j.ijcard.2005.08.068

73.12 'superfoods' you should be eating. Harvard Health Publishing. March 1, 2013. Accessed June 27, 2021. https:// www.health.harvard.edu/staying-healthy/12-superfoodsyou-should-be-eating

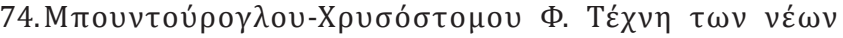

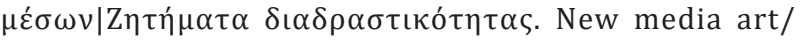
Interactivity matters. Aristotle University of Thessaloniki; 2012. Thesis in Greek. Accessed June 27, 2021. http://ikee. lib.auth.gr/record/131350/files/GRI-2013-10100.pdf

75. Leme ACB, Thompson D, Lenz Dunker KL, et al. Obesity and eating disorders in integrative prevention programmes for adolescents: protocol for a systematic review and meta-analysis. BMJ Open. 2018;8(4):e020381. doi:10.1136/bmjopen-2017-020381

76. Field Trip-Kara Walker: A Subtlety. Samek Art Museum of Bucknell University. Accessed June 27, 2021. https:// museum.bucknell.edu/2014/07/08/field-trip-kara-walkera-subtlety/

77. Newman EL. Female Body Image in Contemporary Art: Dieting, Eating Disorders, Self-Harm, and Fatness. Routledge; 2018. doi:10.4324/9781315229461

78. Cena H, Calder PC. Defining a Healthy Diet: Evidence for The Role of Contemporary Dietary Patterns in Health and Disease. Nutrients. 2020;12(2):334. doi:10.3390/nu12020334

79. Plasek B, Lakner Z, Temesi Á. Factors that Influence the Perceived Healthiness of Food-Review. Nutrients. 2020;12(6):1881. doi:10.3390/nu12061881

80. WHO remains firmly committed to the principles set out in the preamble to the Constitution. Constitution. World Health Organization. Accessed June 27, 2021. https://www.who.int/ about/governance/constitution

81. Graham-Pole J. Illness and the art of creative self-expression: stories and exercises from the arts for those with chronic illness. New Harbinger Publications; 2000.

82. Petterson M. Music for healing: the creative arts program 
at the Ireland Cancer Center. Altern Ther Health Med. 2001;7(1):88-89.

83. Lane MR. Creativity and spirituality in nursing: implementing art in healing. Holist Nurs Pract. 2005;19(3):122-125. doi:10.1097/00004650-200505000-00008

84. LiKamWa A, Cardoso J, Sonke J, Fillingim RB, Booker SQ. The effect of music on pain sensitivity in healthy adults. Arts Health. 2020:1-19. doi:10.1080/17533015.2020.1827278

85. Lewis A, Cave P, Stern M, et al. Singing for Lung Health-a systematic review of the literature and consensus statement. NPJ Prim Care Respir Med. 2016;26:16080. doi:10.1038/npjpcrm.2016.80

86. Boyce M, Bungay H, Munn-Giddings C, Wilson C. The impact of the arts in healthcare on patients and service users: A critical review. Health Soc Care Community. 2018;26(4):458473. doi:10.1111/hsc. 12502

87. Kreitzer MJ, Snyder M. Healing the heart: integrating complementary therapies and healing practices into the care of cardiovascular patients. Prog Cardiovasc Nurs. 2002;17(1):73-80. doi:10.1111/j.0889-7204.2002.00626.x

88. Reynolds F, Lim KH. Contribution of visual art-making to the subjective well-being of women living with cancer: A qualitative study. Arts Psychother. 2007;34(1):1-10. doi:10.1016/j.aip.2006.09.005

89. Monti DA, Peterson C, Kunkel EJ, et al. A randomized, controlled trial of mindfulness-based art therapy (MBAT) for women with cancer. Psychooncology. 2006;15(5):363-373. doi:10.1002/pon.988

90. Stuckey HL, Nobel J. The connection between art, healing, and public health: A review of current literature. Am J Public Health. 2010;100(2):254-263. doi:10.2105/AJPH.2008.156497

91. Moss H, Donnellan C, O'Neill D. A review of qualitative methodologies used to explore patient perceptions of arts and healthcare. Med Humanit. 2012;38(2):106-109. doi:10.1136/medhum-2012-010196

92. Woods HC, Scott H. \#Sleepyteens: Social media use in adolescence is associated with poor sleep quality, anxiety, depression and low self-esteem. J Adolesc. 2016;51:41-49. doi:10.1016/j.adolescence.2016.05.008

93. Glover J, Fritsch SL. \#KidsAnxiety and Social Media: A Review. Child Adolesc Psychiatr Clin N Am. 2018;27(2):171-182. doi:10.1016/j.chc.2017.11.005

94. Marino C, Gini G, Vieno A, Spada MM. The associations between problematic Facebook use, psychological distress and well-being among adolescents and young adults: A systematic review and meta-analysis. J Affect Disord. 2018;226:274-281. doi:10.1016/j.jad.2017.10.007

95. Manske A, Schmidt SJ. Mediatoren der problematischen Nutzung sozialer Medien im Jugendalter als mögliche Wirkmechanismen von psychotherapeutischen Interventionen. Mediators of Problematic Social Media Use in Adolescence as Possible Mechanisms of Change in Psychotherapy. Article in German. Prax Kinderpsychol Kinderpsychiatr. 2019;68(8):690710. doi:10.13109/prkk.2019.68.8.690

96. Aparicio-Martinez P, Perea-Moreno AJ, Martinez-Jimenez MP, Redel-Macías MD, Pagliari C, Vaquero-Abellan M. Social Media, Thin-Ideal, Body Dissatisfaction and Disordered Eating Attitudes: An Exploratory Analysis. Int J Environ Res Public Health. 2019;16(21):4177. doi:10.3390/ijerph16214177

97. Cohen R, Newton-John T, Slater A. The relationship between Facebook and Instagram appearance-focused activities and body image concerns in young women. Body Image. 2017;23:183-187. doi:10.1016/j.bodyim.2017.10.002

98. Gil Á, de Victoria EM, Olza J. Indicadores de evaluación de la calidad de la dieta. Revista Española de Nutrición Comunitaria. 2015;21(Suppl 1):127-143. doi:10.14642/RENC.2015.21.sup1.5060

99. Uhls YT, Ellison NB, Subrahmanyam K. Benefits and Costs of Social Media in Adolescence. Pediatrics. 2017;140(Suppl 2):S67-S70. doi:10.1542/peds.2016-1758E

\section{ACKNOWLEDGEMENTS}

We would like to express our gratitude to Apostolis Tsinoulis for his significant guidance on selecting the paintings which were included in this study, as well as for providing us momentous historical knowledge.

\section{CONFLICTS OF INTEREST}

The authors have completed and submitted the ICMJE Form for Disclosure of Potential Conflicts of Interest and none was reported.

FUNDING

There was no source of funding for this research.

ETHICAL APPROVAL AND INFORMED CONSENT

Ethical approval and informed consent were not required for this study.

\section{DATA AVAILABILITY}

Data sharing is not applicable to this article as no new data were created. 